Conference Paper

\title{
Financial Performance Analysis at PT. Bata Shoes Tbk
}

\author{
Rizki Apriani*, Amelia Fernawati, Dhea Lestari Noor Putri \\ Nusa Putra University, Indonesia
}

*Corresponding author: E-mail: rizki.apriani_ak18@nusaputra.ac.id

\begin{abstract}
This paper discusses the analysis of financial statements at PT Sepatu Bata, Tbk. We as authors want to analyze the ratios of financial statements and the results of analysis of financial report ratios that can measure the performance of PT Sepatu Bata, Tbk. years 2018 - 2019. From the research conducted, the analysis of financial statement ratios is to uses the ratio of liquidity and profitability. We conducted this study aimed to measure how the financial performance of PT Sepatu Bata, Tbk. By using liquidity ratios, profitability ratios. In this study, we use a quantitative descriptive approach which consists of liquidity ratios and profitability ratios as seen from the financial statements of PT Sepatu Bata, Tbk. During the 20182019 period. The results of this study state that liquidity from 2018 to 2019 has decreased by $38.2 \%$. So that the company's ability to be able to pay short-term obligations has increased from $292.7 \%$ in 2018 to $330.9 \%$ in 2019. The Quick Ratio has increased the percentage from 2018 to 2019 , which is $22 \%$. So that the ratio of networking capital to current liabilities increases from $79 \%$ in 2018 to $101 \%$ in 2019. And the Cash Ratio (CR) from 2018 to 2019 has increased by $1.7 \%$. So that the cash ratio has increased from $1.9 \%$ in 2018 to $3.6 \%$ in 2019. Profitability on the profit/loss statement of PT Sepatu Bata, Tbk. that the company can generate profits from sales (Net Profit Margin) in 2018 amounting to $6.8 \%$, and in 2019 by $2.5 \%$. Then the company can make a profit from every one rupiah of assets used (Return on Asset) in 2018 of $7.7 \%$, and 2019 of $2.7 \%$. And the company gets a return for every rupiah of owner's capital (ROE) in 2018 of $10 \%$, and 2019 of $3.5 \%$.
\end{abstract}

Keywords: Financial statement1, liquidity2 and profitability

\section{Introduction}

Financial reports are a final process in the accounting process that has a very important role in measuring and evaluating the performance of a company. Companies in Indonesia in particular and companies that go public are required to prepare financial reports for each period. The objective of these financial reports is to provide information about the company's financial position, company performance, and cash flow which is very useful for most users of the report to make economic decisions and to show management accountability (stewardship) for the use of entrusted resources (Osadchy et al., 2018).

Today many companies, large or small, have a great interest in finance. In the increasingly advanced development of the business world, competition between companies and other companies is getting higher, resulting in companies that suddenly experience setbacks and even bankruptcy (Ooghe \& Prijcker, 2006). Therefore, for a company to survive and thrive, the company must pay close attention to the condition and performance of the company. To know exactly how the condition and performance of the company is also requires proper analysis.

The financial report is a description of the results of the development of the company's business. These financial statements can be used to assist users of financial statements in assessing company performance so that they can make the right decisions (Carraher \& Auken, 2013). The financial perfor-

\section{How to cite:}

Apriani, R., Fernawati, A., \& Putri, D. L. N. (2021). Financial performance analysis at PT. Bata Shoes Tbk . $I^{s t}$ ICEMAC 2020: International Conference on Economics, Management, and Accounting. NST Proceedings. pages 404-411. doi: 
mance of a company can be measured and viewed through financial reports by analyzing financial statements using the financial ratio method. Financial report analysis activities are a medium to obtain more, better, more accurate information and serve as material in the decision-making process.

Financial statement analysis is a very important tool for obtaining information relating to the company's financial position and the results that the company has achieved in connection with the company's strategic selection to be determined. In addition, by analyzing the company's financial statements, company leaders can find out the financial condition of a company and the results that have been achieved in the past and in the current time. As is well known, the main purpose of financial reports is to provide information concerning the financial position, performance, and changes in the financial position of a company that is useful for a large number of users in making economic decisions. That is, the financial report is a tool to obtain information about the financial position and results of operations that have been achieved by a company. This information will later be used as material for consideration in decisionmaking, both by company management and by external parties (Cascio \& Montealegre, 2016).

Based on the description of the background that has been stated above, the authors are interested in choosing the title: "Financial Performance Analysis at PT Sepatu Bata Tbk".

Formulation of The Problem

Based on the background of the problems that have been described above, the problem we will discuss is how is financial performance is measured based on financial statement analysis using the financial ratio method (liquidity ratios and profitability ratios)?

\section{Research Purposes}

To find out how financial performance is measured based on financial statement analysis using the financial ratio method (liquidity ratios and profitability ratios).

\section{Literature Review \\ Financial statements}

In general, a financial report is a file containing records of money. The point is that the financial report is a report that contains all kinds of transactions in which money is involved, be it purchase transactions or sales and credit transactions. Usually, this report is made within a certain period. The determination is determined by company policy whether the financial statements are made every month or once a year. Sometimes companies also use both. This financial report is made to determine the company's financial condition (Hasanaj \& Kuqi, 2019). So that superiors can evaluate appropriately if the business's financial condition has problems. Therefore, this financial report must be prepared accurately and carefully. Because this is in the form of a report, of course, there is a responsibility that is left absolutely to the financial operator. He must present the report he has made in detail in front of his superior. Usually, this is done during the evaluation. In short, the financial report is a file containing data on the company's financial transactions for a certain period. where the file must be reported and accounted for as an evaluation discussion for future business developments.

Susilo (2009) concludes that the financial report is the final result of the accounting process which contains information and provides information about the company's economic data which consists of lists showing the financial position and results of the company's activities for a period including balance sheets, earnings reports. loss, and changes in financial statements.

\section{Purpose of financial statements}

The main purpose of the most important financial statements is to provide useful information for investors and creditors in making investment and credit decisions (Osadachy et al., 2018). The specific purpose of financial statements is to present the financial position, results of operations, and other changes in financial position on a mandatory basis and following generally accepted accounting principles.

While the general purpose of financial statements is divided as follows (Healy \& Palepu, 2001): 
- Providing reliable information. Information is given about economic resources and corporate obligations, to assess the strengths and weaknesses of the company.

- Shows the company's financial and investment position

- Assess the company's ability to pay off its obligations

- Demonstrate the capabilities of existing resources for company growth

- Provide information on sources of wealth

- Provide reliable information about the source of net worth that comes from business activities in search of profit.

This is intended to provide an overview of the number of dividends expected by shareholders. Demonstrate the company's ability to pay its obligations to creditors, suppliers, employees, government, and the ability to raise funds for company expansion purposes. Provide information to management to be used in the implementation of planning and control functions. Shows the level of the company's ability to get long-term profits, provides other necessary information about changes in assets and liabilities. Disclose other relevant information required by report users.

In the Financial Accounting Standards, it has been explained that the most important purpose of financial statements is to provide information concerning the financial position, performance, and changes in the financial position of a company which is useful for a large number of users in making decisions.

\section{Liquidity ratio}

Liquidity Ratio is a ratio that aims to find out how the company's ability to pay short-term obligations. means that if the company is subject to billing, it will be able to meet these debt obligations, including debts that are due.

\section{Liquidity ratios include:}

Current Ratio, which means the ability of the company's current assets to meet short-term liabilities with current assets owned by the company. This short-term liquidity is very important because shortterm cash flow problems can result in a company going bankrupt.

CR $\frac{\text { Current asset }}{\text { current debt }} \times 100 \%$

Quick Ratio (QR) is a company's ability to pay its obligations that must be fulfilled immediately with current, more liquid assets (quick assets), or networking capital. The ratio of net working capital is used to determine the ratio of net capital to current liabilities. A company will be said to be healthy if the ratio is more than one or more than $100 \%$.

$$
Q R=\frac{\text { current asset }- \text { current debt }}{\text { current liabilities }} \times 100 \%
$$

Cash Ratio (CR), which means the company's ability to pay its obligations that must be fulfilled immediately with available cash in the company and the following securities or short-term securities that can be immediately cashed.

$C R=\frac{\text { cash }}{\text { current liabilities }} \times 100 \%$ 


\section{Profitability Ratio}

The profitability ratio is used to find out how the company's ability to get a profit or profit. This ratio is usually a benchmark for business continuity. Profitability ratios include:

Net Profit Margin (NPM), this ratio can describe the amount of net profit that the company gets on every sale made.

$N P M=\frac{\text { net profit }}{\text { revenue }} \times 100 \%$

Return On Asset (ROA). This ratio illustrates how the company's ability to generate profits from every one dollar of assets used.

$R O A=\frac{\text { net profit }}{\text { assets }} \times 100 \%$

Return On Equity (ROE), this ratio can be used to determine the amount of return given by the company for every rupiah of capital from the owner.

$R O E=\frac{\text { net } \text { income }}{\text { capital }} \times 100 \%$

Framework

Based on the explanation above, the framework of this research is as follows:

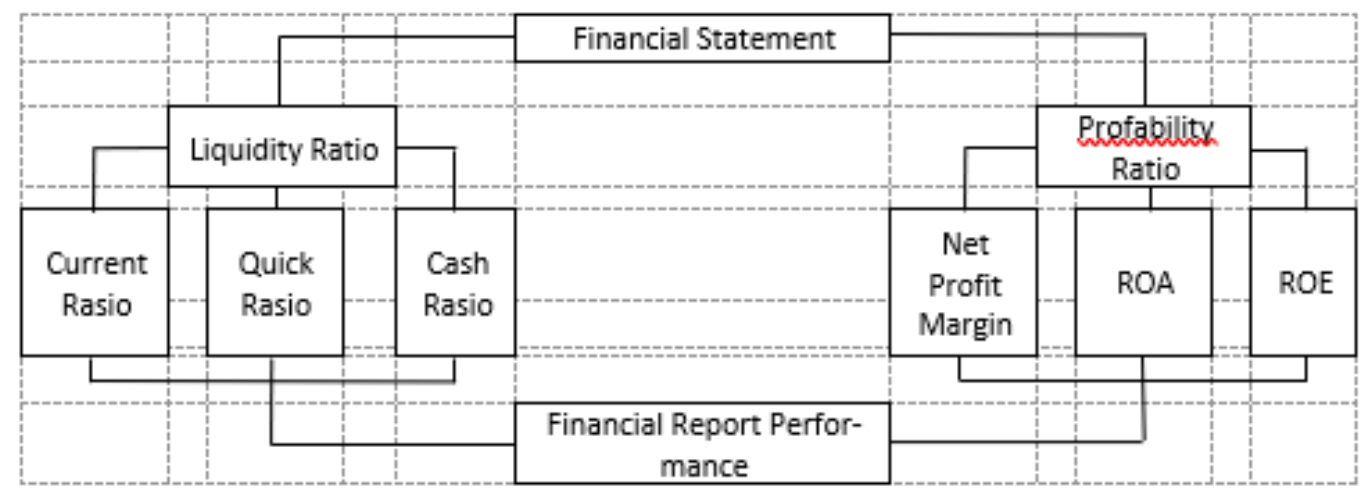

Figure 1. The framework of the research

\section{Material and Methods}

Object of research

The object of this research is PT Sepatu Bata Tbk. which is located at Jl. RA. Kartini Kav. 28, Cilandak Barat, RT.8 / RW.8, Cilandak Bar., Kec. Cilandak, City of South Jakarta, Special Capital Region of Jakarta 12430 .

\section{Data source}

In this study, we use secondary data, where the data taken is data obtained from the company as the object of research. The data we need in this study is qualitative data which is an overview of the company PT Sepatu Bata, Tbk. and quantitative where the data is in the form of numbers listed in the financial statements and income statements for the period 2018-2019 from PT Sepatu Bata, Tbk. which have been published and listed on the Indonesia Stock Exchange. 


\section{Method of collecting data}

Data collection is done by collecting library data from several sources and documents related to financial reports by reading and using literature related to the discussion of this research.

\section{Data analysis}

In analyzing the author uses descriptive methods and ratio analysis. Where the authors collect data, process data, and interpret it then analyze it using the method of liquidity ratios and profitability to company finances.

\section{Results and Discussion \\ Research result}

Based on the data we got from the financial statements of PT Sepatu Bata, Tbk. that we get then we analyze using liquidity ratios and profitability ratios. The liquidity ratio is the ratio used to determine the company's ability to pay short-term obligations. And the profitability ratio is a ratio that describes the company's ability to generate profits. The calculation of the liquidity ratio and profitability ratio at PT Sepatu Bata, Tbk. namely as follows:

\section{Liquidity ratio}

Current ratio

$C R=\frac{\text { current asset }}{\text { current debt }} \times 100 \%$

$C R 2018=\frac{569.545 .551}{194.538 .478} \times 100 \%=292,7 \%$

$C R 2019=\frac{164.585 .862}{164.585 .862} \times 100 \%=330,9 \%$

Quick Ratio $(Q R)$

$$
\begin{aligned}
& Q R=\frac{\text { current asset }- \text { current debt }}{\text { current liabilities }} \times 100 \% \\
& Q R 2018=\frac{569.545 .551-377.713 .945}{240.408 .566} \times 100 \%=79 \% \\
& Q R 2019=\frac{544.652 .375-342.406 .771}{209.895 .228} \times 100 \%=101 \%
\end{aligned}
$$

\section{Cas Ratio (CR)}

$$
\begin{aligned}
& C R=\frac{\text { cash }}{\text { current liabilities }} \times 100 \% \\
& C R 2018=\frac{4.688 .596}{240.048 .866} \times 100 \%=1,9 \% \\
& C R 2019=\frac{7.685 .512}{209.895 .228} \times 100 \%=3,6 \%
\end{aligned}
$$


From the calculation of the liquidity ratio above, it can be seen the percentage result ratio in the following table:

Table 1 . See the percentage result ratio

\begin{tabular}{|c|c|c|}
\hline \multirow[t]{2}{*}{ Liquidity } & \multicolumn{2}{|c|}{ Year } \\
\hline & 2018 & 2019 \\
\hline Current Ratio & $292,70 \%$ & $330,90 \%$ \\
\hline Quick Ratio & $79 \%$ & $101 \%$ \\
\hline Cash Ratio & $1,90 \%$ & $3,60 \%$ \\
\hline
\end{tabular}

\section{Profitability Ratio}

Net Profit Margin (NPM)

$N P M=\frac{\text { net profit }}{\text { revenue }} \times 100 \%$

$N P M 2018=\frac{67.944 .807}{992.696 .071} \times 100 \%=6,8 \%$

$N P M 2019=\frac{23 \cdot 441.338}{931 \cdot 271.436} \times 100 \%=2,5 \%$

Return On Asset (ROA)

$R O A=\frac{\text { net profit }}{\text { assets }} \times 100 \%$

$R O A 2018=\frac{67.944 .8678}{76.856 .225} \times 100 \%=7,7 \%$

$R O A 2019=\frac{23.441 .338}{863.146 .554} \times 100 \%=2,7 \%$

Return On Equity (ROE)

$R O E=\frac{\text { net income }}{\text { capital }} \times 100 \%$

$R O E 2018=\frac{67.944 .867}{636.807 .359} \times 100 \%=10 \%$

$R O E 2019=\frac{23.441 .338}{653.251 .328} \times 100 \%=3,5 \%$

From the calculation of the profitability ratio above, we can see the percentage yield ratio in the following table: 
Table 2. The percentage yield ratio

\begin{tabular}{lcc}
\multicolumn{1}{c}{ Profitability } & \multicolumn{2}{c}{ Year } \\
& 2018 & 2019 \\
\hline Net Profit Margin (NPM) & $6,80 \%$ & $2,50 \%$ \\
Return On Asset (ROA) & $7,70 \%$ & $2,70 \%$ \\
Return On Equity (ROE) & $10,00 \%$ & $3,50 \%$ \\
\hline
\end{tabular}

\section{Discussion}

Liquidity

From the table above, it can be seen that from 2018 to 2019 it decreased by $38.2 \%$. So that the company's ability to be able to pay short-term obligations has increased from $292.7 \%$ in 2018 to $330.9 \%$ in 2019.

Then the Quick Ratio has increased the percentage from 2018 to 2019 , which is $22 \%$. So that the ratio of networking capital to current liabilities increases from $79 \%$ in 2018 to $101 \%$ in 2019

And then the Cash Ratio (CR) from 2018 to 2019 has increased by $1.7 \%$. So that the cash ratio has increased from 1.9 in 2018 to $3.6 \%$ in 2019.

\section{Profitability}

In the table above, the comparison of profitability ratios on the profit/loss statement of PT Sepatu Bata, Tbk. that the company can generate profits from sales (Net Profit Margin) in 2018 amounting to 6.8\%, and in 2019 by $2.5 \%$. Then the company can make a profit from every one rupiah of assets used (Return on Asset) In the table above, the comparison of profitability ratios on the profit/loss statement of PT Sepatu Bata, Tbk. that the company can generate profits from sales (Net Profit Margin) in 2018 amounting to $6.8 \%$, and in 2019 by $2.5 \%$. Then the company can make a profit from every one rupiah of assets used (Return on Asset) in 2018 of $7.7 \%$, and 2019 of $2.7 \%$. And the company gets a return for every rupiah of owner's capital (ROE) in 2018 of $10 \%$, and 2019 of $3.5 \%$

\section{Conclusion}

Based on the results of the analysis that has been carried out using liquidity and profitability ratios regarding the Financial Statements and Profit / Loss Statements of PT Sepatu Bata, Tbk. as a whole it can be concluded as follows:

Liquidity from the table above, it can be seen that from 2018 to 2019 has decreased by $38.2 \%$. Can pay short-term obligations has increased from $292.7 \%$ in 2018 to $330.9 \%$ in 2019 . Then the Quick Ratio has increased the percentage from 2018 to 2019 , which is $22 \%$. So that the ratio of networking capital to current liabilities increases from 79\% in 2018 to $101 \%$ in 2019. And the Cash Ratio (CR) from 2018 to 2019 has increased by $1.7 \%$. So that the cash ratio has increased from 1.9 in 2018 to $3.6 \%$ in 2019 .

Profitability from the table above, the comparison of profitability ratios on the profit/loss statement of PT Sepatu Bata, Tbk. that the company can make a profit from sales (Net Profit Margin) on a profit of $6.8 \%$ in 2018, and $2.5 \%$ in 2019. Then the company can make a profit from every one rupiah of assets used (Return on Asset) in 2018 of $7.7 \%$, and 2019 of $2.7 \%$.

\section{Acknowledgment}

We would like to thank all those who have helped to complete this article.

\section{References}

Carraher, S. M., \& Auken, H. V. (2013). The use of financial statements for decision-making by small firms. Journal of Small Business \& Entrepreneurship, 26(3), 323-336. Doi:10.1080/08276331.2013.803676

Cascio, W. F., \& Montealegre, R. (2016). How Technology Is Changing Work and Organizations. Annual Review of Organizational Psychology and Organizational Behavior, 3(1), 349-375. DOI:10.1146/annurev-orgpsych-041015-062352 
Hasanaj, P., \& Kuqi, B. (2019). Analysis of financial statements. Humanities and Social Science Research, $2(2), 17$. DOI: $10.30560 /$ hssr.v2n2p17

Healy, P. M., Palepu, K. G. (2001). Information asymmetry, corporate disclosure, and the capital markets: A review of the empirical disclosure literature. Journal of Accounting and Economics, 31(2001), 405-440.

Ooghe, H., \& Prijcker, S. D. (2006). Failure processes and causes of company bankruptcy: A typology. Management Decision 46(2), 1-5. Doi:10.1108/00251740810854131

Osadachy, E. A., Akhmetshin, E., Amirova, E. F., Bochkareva, T. N., Gazizyanova, Y. Y., \& Yumashev, A. V. (2018). Financial statements of a company as an information base for decision-making in a transforming economy. European Research Studies Journal, 21(2), 339350

Susilo, B. (2009). Financial statement analysis to assess company financial performance. Essay. Muhammadiyah University. Surakarta 